\title{
PENGARUH METODE FIELD TRIP TERHADAP KEMAMPUAN MENULIS KARANGAN DESKRIPSI SISWA KELAS X SMA NEGERI 3 PANDEGLANG \\ Oleh
}

\author{
Trisnawati (enatrisna1 @gmail.com) \\ Dosen Program Studi Pendidikan Bahasa, Sastra Indonesia, dan Daerah \\ Universitas Mathla’ul Anwar Banten
}

\begin{abstract}
ABSTRAK
Penelitian bertujuan untuk mengetahui pengaruh metode field trip terhadap kemampuan menulis karangan deskripsi siswa kelas X SMAN 3 Pandeglang tahun pelajaran 2016/2017. Metode yang digunakan dalam penelitian ini adalah metode eksperimen dengan posttest only control design. Populasi dari penelitian ini adalah seluruh siswa SMAN 3 Pandeglang. Sampel dalam penelitian ini adalah siswa kelas X SMAN 3 Pandeglang yang diambil dua kelas secara acak. Instrumen yang digunakan dalam penelitian ini terdiri dari tes kemampuan menulis karangan deskripsi. Hasil uji hipotesis menunjukkan nilai $t_{\text {hitung }} 12,29$ sedangkan nilai $t_{\text {tabel }}$ adalah 1,995. Berdasarkan uji hipotesis diperoleh kesimpulan bahwa terdapat pengaruh metode field trip terhadap kemampuan menulis karangan deskripsi siswa kelas $\mathrm{X}$ SMAN 3 Pandeglang tahun pelajaran 2016/2017.
\end{abstract}

Kata Kunci : Metode field trip dan kemampuan menulis karangan deskripsi

\section{PENDAHULUAN}

Pengajaran bahasa Indonesia mengalami perkembangan yang sangat pesat mulai dari cara pendekatan, strategi, teknik, metode dan media. Pengajaran bahasa Indonesia yang inovatif dan variatif mulai diterapkan guru bahasa Indonesia. Tujuan adanya pola pengajaran tersebut adalah dalam rangka pencapaian kompetensi siswa dalam bidang-bidang tertentu, salah satunya adalah penguasaan keterampilan dalam bidang bahasa Indonesia turut mendapat perhatian.

Keterampilan berbahasa yang harus dikuasai oleh siswa meliputi empat komponen yaitu keterampilan menyimak, keterampilan berbicara, keterampilan membaca, dan keterampilan menulis. Salah satu keterampilan berbahasa yang perlu mendapatkan perhatian sungguhsungguh adalah keterampilan menulis, karena keterampilan menulis siswa masih kurang dan rendah. Keterampilan menulis tidak datang secara otomatis, melainkan harus melalui latihan dan praktik yang teratur.

Pengajaran keterampilan menulis yang kreatif dapat memberikan manfaat untuk melatih dan mendorong siswa untuk mengekspresikan diri dalam tulisan. Pengajaran menulis merupakan keterampilan produktif yang menuntut kemampuan siswa untuk mengungkapkan 
ide, gagasan, pesan, perasaan dan daya khayal serta menggunakan bahasa yang tepat. Tetapi, pada kenyataannya penguasaan bahasa Indonesia masih kurang baik.

Mengingat pentingnya keterampilan menulis dalam kegiatan pembelajaran, siswa perlu dibina untuk mengembangkan keterampilan menulisnya melalui pembelajaran menulis. Salah satu jenis keterampilan menulis tersebut adalah keterampilan menulis karangan deskripsi. Karangan deskripsi adalah jenis karangan yang menggambarkan atau melukiskan objek tertentu dengan detail, jelas dan sesuai keadaan yang sebenar-benarnya tentang objek yang dilukiskan. Semua hal yang ada di dalam objek tersebut digambarkan melalui pengamatan pancaindera, dari segala sesuatu yang bisa didengar, dilihat, dicium, dan dirasa. Semua gambaran itu dirangkai dalam bentuk kata-kata, kalimat-kalimat, paragraf-paragraf hingga membentuk suatu karangan yang utuh. Tujuan menulis karangan deskripsi, yaitu pembaca seolah-olah dapat merasakan dan melihat secara langsung objek yang digambarkan oleh sang penulis melalui karangannya.

Dalam menulis karangan deskripsi siswa diberikan pelatihan dalam menulis karangan deskripsi, siswa diharapkan mampu menguasai kompetensi dasar yang ingin dicapai. Akan tetapi, dalam kenyataannya tidak semua kompetensi dapat tercapai dengan baik. Kompetensi ini akan tercapai apabila siswa telah mampu menjelaskan pengertian dan karakteristik karangan deskripsi, siswa mampu menentukan tema dan mengidentifikasi topik yang akan dikembangkan menjadi karangan deskripsi, siswa mampu mengembangkan tema dan topik serta menulis karangan deskripsi berdasarkan hasil pengamatan dengan memperhatikan aturan tata tulis kebahasaan, dan siswa mampu menyunting karangan deskripsi yang telah ditulis.

Permasalahan yang penulis alami ketika melakukan observasi di lapangan yaitu penulis menemukan bahwa kemampuan siswa dalam menulis karangan deskripsi masih rendah. Nilai yang diperoleh siswa dalam kompetensi dasar ini belum mencapai standar ketuntasan yang telah ditetapkan, yaitu 70. Lemahnya kemampuan siswa dalam menulis karangan deskripsi tersebut karena lemahnya penguasaan siswa terhadap indikator pembelajaran. Indikator pembelajaran yang telah dirumuskan oleh guru sebelumnya ternyata belum semuanya dapat tercapai dengan maksimal dan baik. Hal ini disebabkan guru memberikan materi masih secara konvensional (metode ceramah). Guru hanya memberikan materi, siswa mencatat dan latihan.

Selain lemahnya penguasaan siswa terhadap tiap-tiap indikator pembelajaran, ketidaktercapaian tujuan pembelajaran menulis karangan deskripsi disebabkan siswa merasa bosan belajar di dalam kelas, siswa tidak senang dengan materi menulis karangan deskripsi 
yang monoton, terbatasnya kemampuan siswa dalam berimajinasi dan memberikan kesan hidup pada objek karangan dan siswa juga belum bisa memaksimalkan penginderaan dalam menulis karangan deskripsi. Guru pada umumnya mengajar keterampilan menulis dengan tahapan-tahapan guru mengajar selalu dengan ceramah, guru memberikan contoh dan langsung menyuruh siswa mengarang dengan topik tertentu, siswa mengarang dengan topik yang telah ditentukan oleh guru, dan guru mengoreksi hasil karangan siswa dan memberi nilai pada siswa. Dengan demikian, siswa tidak mengetahui kekurangan atau kelemahan yang ada pada dirinya. Untuk itu, hasil latihan siswa harus dibicarakan dan didiskusikan sehingga siswa mengetahui kesalahannya. Dengan mengetahui kesalahannya, siswa akan berusaha untuk memperbaikinya sehingga dalam menyelesaikan tugas menulis karangan deskripsi hasilnya akan lebih baik.

Masalah-masalah yang mempengaruhi keterampilan menulis karangan deskripsi dalam pembelajaran memerlukan tindakan berupa pendekatan, model, metode, teknik, strategi, dan media pembelajaran yang baru, untuk meningkatkan kemampuan menulis karangan deskripsi. Salah satu metode yang dapat digunakan untuk meningkatkan kemampuan menulis karangan deskripsi adalah metode field trip.

Metode field trip adalah salah satu metode mengajar yang dilaksanakan dengan cara mengajak para siswa mengunjungi tempat tertentu yang dapat digunakan untuk belajar. Pelaksanaan pembelajaran dengan metode field trip guru akan membimbing siswa mengunjungi tempat-tempat yang dapat dijadikan objek belajar. Siswa akan mengamati dan menggali informasi penting yang diperoleh di tempat field trip. Siswa akan mencatat hal-hal yang dilihat, ditemui dan dirasakan ketika mengunjungi tempat tersebut. Bahan-bahan yang diperoleh di tempat field trip itu akan dituangkan dalam bentuk karangan deskripsi. Penerapan metode field trip diharapkan dapat meningkatkan kepekaan siswa sehingga siswa tidak mengalami hambatan ketika menulis karangan deskripsi, karena sudah memperoleh bahan tulisan dari objek langsung yang diamati ketika melaksanakan field trip. Dengan melihat langsung objek yang diamati, siswa akan lebih mudah dalam mendeskripsikan objek dan menuangkan ide, perasaan, atau gagasan ke dalam sebuah bentuk ekspresi dalam bentuk karangan, sehingga siswa dapat membuat tulisan yang runtut dan logis berdasarkan objek yang diamatinya.

\section{Pengertian Menulis}

Menulis merupakan kegiatan keterampilan berbahasa dengan menuangkan ide, pikiran dan gagasan pada sebuah tulisan. Menurut Suparno dan Yunus (Dalman, 2015:4) bahwa menulis merupakan suatu kegiatan penyampaian pesan (komunikasi) dengan menggunakan 
bahasa tulis sebagai alat atau medianya. Selain itu, Tarigan (Dalman, 2015:4) mengemukakan bahwa menulis ialah menurunkan atau melukiskan lambang-lambang grafis yang menghasilkan suatu bahasa yang dipahami oleh seseorang sehingga orang lain dapat membaca lambang-lambang grafis tersebut dan memahami bahasa lain grafis itu. Marwoto (Dalman, 2015:5) menjelaskan bahwa menulis adalah mengungkapkan ide atau gagasan dalam bentuk karangan secara leluasa, dalam hal ini menulis membutuhkan skema yang luas sehingga si penulis mampu menuangkan ide, gagasan, pendapatnya dengan mudah dan lancar, skema itu sendiri adalah pengetahuan dan pengalaman yang dimiliki. Jadi, semakin luas skema seseorang semakin mudah ia menulis. Menulis merupakan kegiatan berupa penuangan ide atau gagasan dengan kemampuan yang kompleks melalui aktivitas yang aktif produktif dalam bentuk simbol huruf angka secara sistematis sehingga dapat dipahami oleh orang lain.

Tujuan menulis bagi setiap orang berbeda-beda, tujuan yang hendak dicapai dirumuskan secara jelas karena tujuan menulis yang dirumuskan dengan jelas akan memberikan andil yang besar terhadap isi tulisan yang hendak dibuat. Semi (2007:14-21) menguraikan tujuan menulis adalah untuk menceritakan sesuatu, menulis memberikan petunjuk atau pengarahan, menulis menjelaskan sesuatu untuk meyakinkan orang lain tentang suatu pendapat, sehingga orang lain dapat meyakini pendapat dan pandangan penulis, dan menulis merangkum bacaan yang panjang menjadi lebih pendek sehinggga lebih mudah dipahami.

Menulis dapat memberikan manfaat yang besar, menurut Nursisto (1999 : 5-6) memaparkan manfaat menulis sebagai sarana mengungkapkan diri dan mampu mengungkapkan perasaan seseorang, menulis sebagai sarana untuk memahami sesuatu dan mengungkapkan gagasan sehingga pembaca dapat memperoleh pemahaman yang baru tentang sesuatu yang ditulisnya, menulis sebagai sarana untuk mengembangkan kepuasan pribadi, kebanggaan dan rasa harga diri untuk membangkitkan kepercayaan terhadap kemampuan diri sendiri untuk melahirkan karya tulis lainnya, menulis sebagai sarana untuk meningkatkan kesadaran terhadap lingkungan sekeliling, menulis dapat mempertinggi kesiaagaan indera seseorang dalam mengembangkan daya serapan pada tingkat jasmani maupun rohani, menulis sebagai sarana untuk melibatkan diri dengan semangat dan menulis sebagai sarana untuk mengembangkan pemahaman dan kemampuan menggunakan bahasa. Menulis akan menjadikan seseorang mampu menggunakan kata-kata dalam tulisan untuk menyampaikan keterangan kepada orang lain sehingga orang lain dapat mengetahui apa yang ditulisnya. Akhadiah dkk, (2001:1-2) memaparkan manfaat menulis yaitu dapat mengenali kemampuan diri, dapat mengembangkan berbagai gagasan, dapat lebih banyak menyerap, 
mencari dan menguasai informasi, dapat menjelaskan permasalahan, dapat menilai gagasan sendiri secara objektif, dapat menganalisis dan memecahkan permasalahan, dapat mendorong lebih aktif belajar dan dapat terbiasa berpikir dan berbahasa secara lebih tertib.

Berdasarkan uraian diatas, penulis dapat menyimpulkan bahwa banyak sekali manfaat yang dapat diperoleh dari kegiatan menulis. Menulis dapat dijadikan sebagai sarana untuk berkomunikasi antara penulis dan pembaca melalui media tulisan. Dengan menulis, seseorang akan memiliki rasa percaya diri, kepuasan pribadi, kebanggaan terhadap karya-karyanya, dan dapat mengembangkan pemahaman serta kreatifitas berpikir seseorang untuk menuangkan ide dan gagasannya.

\section{Karangan Deskripsi}

Menurut Tarigan (2008:21) bahwa karangan merupakan pikiran atau gagasan yang disampaikan kepada orang lain dalam bahasa tulis. Menurut Tim Penyusun Kamus Pusat bahasa (2005:258) bahwa kata deskripsi didefinisikan sebagai pemaparan atau penggambaran dengan kata-kata secara jelas dan terperinci serta uraian. Nursisto (1999:40) menjelaskan, bahwa deskripsi adalah karangan yang melukiskan sesuatu sesuai keadaan yang sebenarnya sehingga pembaca mampu merasakan dan melihat apa yang dilukiskan oleh penulisnya. Finoza (2009:239-240) mengemukakan bahwa deskripsi adalah bentuk tulisan yang bertujuan memperluas pengetahuan dan pengalaman pembaca dengan jalan melukiskan hakikat objek yang sebenarnya. Deskripsi berasal dari kata "describe" yang berarti menulis tentang, membeberkan, atau melukiskan sesuatu hal. Dalam bidang karang-mengarang, deskripsi dimaksudkan sebagai suatu karangan yang digunakan penulis untuk memindahkan kesankesannya, memindahkan hasil pengamatannya dan perasaannya, dan disajikan kepada para pembaca. Maryuni (2007:11) menjelaskan, bahwa karangan deskripsi adalah karangan yang menggambarkan, memberikan suatu peristiwa atau objek suatu hasil penginderaan dengan sehidup-hidupnya dan disertai data-data yang kuat sehingga pembaca merasa seolah-olah terlibat di dalamnya secara langsung.

Langkah-langkah menyusun karangan deskripsi menurut Dalman (2015:99) yaitu tentukan objek atau tema yang akan dideskripsikan, tentukan tujuan, mengumpulkan data dengan mengamati objek yang akan dideskripsikan, menyusun data tersebut ke dalam urutan yang baik (sistematis) atau membuat kerangka karangan, dan menguraikan atau mengembangkan kerangka karangan yang menjadi karangan deskripsi yang sesuai dengan tema yang ditentukan. Langkah-langkah menyusun deskripsi harus sesuai dengan aturan yang berlaku, sehingga dalam membuat karangan deskripsi dapat tersusun dengan baik dan isi 
yang terkandung di dalamnya dapat diterima oleh pembaca dan seolah-olah pembaca dapat melihat, mendengar dan merasakannya.

\section{Metode Field Trip}

Sugihartono, dkk. (2007:82) berpendapat bahwa metode field trip adalah cara penyampaian materi pelajaran dengan cara membawa siswa langsung ke objek di luar kelas atau di lingkungan kehidupan nyata agar siswa dapat mengamati atau mengalami secara langsung. Roestiyah N.K. (2001:85) menegaskan, karyawisata ialah cara mengajar yang dilaksanakan dengan mengajak siswa ke suatu tempat atau objek tertentu di luar sekolah untuk mempelajari sesuatu. Hal ini bukan sekedar rekreasi, melainkan untuk belajar dengan melihat kenyataan secara langsung. Menurut Hamdayama (2014:171) menyatakan bahwa metode field Trip (karya wisata) adalah metode pembelajaran dengan cara mengunjungi suatu objek tertentu, misalnya museum, pabrik, dan tempat-tempat lainnya. Metode field trip adalah cara penyampaian materi pelajaran dengan mengajak siswa berkunjung ke sebuah objek agar dapat mengamati objek secara langsung. Metode field trip yang diterapkan dalam penelitian ini dilakukan dengan cara mengajak para siswa mengunjungi objek yang berada di lingkungan sekitar sekolah. Kegiatan yang dilakukan di tempat field trip adalah mengamati objek, menggali informasi dan mencatat untuk dijadikan bahan yang akan ditulis menjadi sebuah karangan deskripsi.

Roestiyah (2001:86) memaparkan, langkah-langkah yang harus dilaksanakan dalam pembelajaran dengan metode field trip adalah merumuskan tujuan intruksional yang jelas, menetapkan objek yang hendak dipilih, menyusun rencana belajar bagi siswa, merencanakan sarana belajar yang ditentukan, melaksanakan proses pembelajaran di tempat, mengawasi pelaksanaan pembelajaran, memberikan bimbingan kepada para siswa, mendiskusikan hasil yang diperoleh di tempat field trip, dan membimbing siswa menyusun karangan.

\section{METODE PENELITIAN}

Metode yang digunakan dalam penelitian adalah metode eksperimen dengan teknik uji-t metode teknik uji-t metode ini dimaksudkan untuk memperoleh gambaran tentang pengaruh penggunaan metode field trip terhadap kemampuan menulis karangan deskripsi. Dengan menggunakan metode ini peneliti berusaha melakukan kegiatan pembelajaran di dua kelas

yakni kelas eksperimen (menggunakan metode field trip) dan kelas kontrol (menggunakan metode ceramah). Desain dalam penelitian ini adalah desain yang hanya menggunakan posttes, desain ini dapat digambarkan sebagai berikut. 
Desain Penelitian

\begin{tabular}{|c|l|l|}
\hline Kelas & Variabel Terikat & Post-tes \\
\hline Eksperimen & $\mathrm{X}$ & $T_{2}$ \\
Kontrol & $\mathrm{O}$ & $T_{2}$ \\
\hline
\end{tabular}

Keterangan :

$\mathrm{X}=$ Perlakuan yang diberikan kepada kelas eksperimen berupa penggunaan metode field trip

$\mathrm{O}=$ Perlakuan yang diberikan kepada kelas kontrol berupa metode ceramah

$T_{2}=$ Test kemampuan menulis karangan deskripsi setelah dilakukan pembelajaran.

(Subana dan Sudrajat, 2001: 100).

Rancangan ini disebut sebagai the state grop comparison : Randomizen Controlgrop Only Design. Dalam rancangan ini sekelompok subjek yang diambil dari populasi tertentu dikelompokkan secara rambang menjadi dua kelompok, yaitu kelompok eksperimen dan kelompok kontrol, yaitu satu kelas sebagai kelompok eksperimen dan satu kelas lagi sebagai kelompok kontrol. Dalam hal ini kelas eksperimen terdiri dari bahan ajar yang berkaitan dengan pembelajaran dan mendapat perlakuan khusus dengan menggunakan metode pembelajaran field trip. Sedangkan kelompok kontrol mendapatkan materi pembelajaran dengan model pembelajaran ceramah. Kedua kelompok itu dikenai pengukuran yang sama. Perbedaan yang timbul dianggap bersumber pada variabel perlakuan. Metode eksperimen digunakan untuk mengetahui dampak dan perbedaan yang ditimbulkan oleh pembelajaran dengan menggunakan metode pembelajaran field trip terhadap hasil belajar menulis karangan deskripsi.

\section{HASIL PENELITIAN DAN PEMBAHASAN}

\section{Hasil Penelitian}

Berdasarkan hasil penelitian menunjukkan bahwa kelas eksperimen memiliki hasil tes kemampuan menulis karangan deskripsi lebih baik dibandingkan kelas kontrol, yang ditunjukkan dengan perbedaan nilai rata-rata kelas eksperimen dan kelas kontrol, yaitu ratarata kelas eksperimen adalah 77 lebih besar daripada nilai rata-rata kelas kontrol 60,28. Kemampuan menulis karangan deskripsi menggunakan metode field trip berkategori baik, hal ini terlihat dari hasil kemampuan menulis karangan deskripsi pada kelas eksperimen (metode field trip) mendapatkan nilai rata-rata 77. Kemampuan menulis karangan deskripsi menggunakan metode ceramah berkategori cukup, hal ini terlihat dari hasil kemampuan 
menulis karangan deskripsi pada kelas kontrol (metode ceramah) mendapatkan nilai rata-rata 60,28 .

Rata-rata kemampuan menulis karangan deskripsi antara kelas eksperimen dan kelas kontrol memiliki selisih sebesar 16,72. Hal ini menunjukkan ada perbedaan yang sesungguhnya antara nilai rata-rata kelas eksperimen dan kelas kontrol, yaitu rata-rata kelas eksperimen adalah 77 lebih besar daripada nilai rata-rata kelas kontrol 60,28.

Hasil uji hipotesis menunjukkan nilai $t_{\text {hitung }} 12,29$ sedangkan nilai $t_{\text {tabel }}$ adalah 1,995 . Artinya terdapat pengaruh metode field trip terhadap kemampuan menulis karangan deskripsi. Hasil uji-t nilai kemampuan menulis karangan deskripsi menunjukkan bahwa nilai kemampuan menulis karangan deskripsi kelas eksperimen lebih baik jika dibandingkan dengan kelas kontrol serta rata- rata nilai akhir kelas eksperimen lebih tinggi daripada kelas kontrol. Pada kelas eksperimen, siswa dapat mengamati objek yang dipelajari secara langsung sedangkan pada kelas kontrol, siswa hanya mendapatkan materi secara ceramah. Adanya kesempatan pengamatan dan pengalaman secara langsung yang diperoleh siswa kelas eksperimen inilah yang mempengaruhi hasil belajar siswa kelas eksperimen lebih baik dari kelas kontrol. Kegiatan tersebut membuat siswa pada kelas eksperimen menjadi lebih baik dalam mendeskripsikan objek yang diamati dengan teliti dan benar, sehingga dapat meningkatkan pemahaman siswa.

\section{Pembahasan}

Hasil belajar siswa dipengaruhi oleh faktor dari dalam diri siswa berupa kesiapan belajar, perhatian, motivasi, minat, ketekunan, tingkat sosial ekonomi, psikis dan fisik siswa, serta faktor dari luar berupa guru, suasana belajar, fasilitas, sumber belajar yang tersedia, dan karakteristik sekolah. Pada penelitian ini yang paling berpengaruh terhadap hasil belajar siswa dari faktor internal siswa berupa perhatian dan motivasi siswa serta faktor eksternal berupa guru, suasana belajar dan sumber belajar. Hal tersebut menyebabkan nilai akhir kelas eksperimen tidak terlalu berbeda jauh dengan kelas kontrol. Adanya faktor kondisi suasana belajar yang baru pada kelas eksperimen, membuat siswa merasa senang dan perhatiannya lebih terfokus pada hal-hal baru yang mereka jumpai. Kondisi tersebut menyebabkan siswa kurang fokus dalam belajar maupun memperhatikan materi dan arahan dari guru. Hal ini berbeda dengan kelas kontrol yang siswanya lebih mudah untuk memfokuskan perhatiannya terhadap materi yang disampaikan guru. Siswa pada kelas kontrol tidak terganggu dengan suasana lingkungan karena sudah terbiasa belajar di dalam kelas dan kondisinya lebih 
nyaman. Namun, jika dilihat dari segi motivasi siswa pada kelas eksperimen memiliki motivasi yang lebih untuk mempelajari hal baru.

Penerapan metode field trip dapat meningkatkan aktivitas siswa karena pada metode field trip siswa dituntut untuk aktif dalam pembelajaran dan memberikan pengalaman secara langsung yang merupakan salah satu keunggulan dari metode field trip.

\section{PENUTUP}

Berdasarkan penelitian dan hasil analisis data, penulis merumuskan beberapa simpulan sebagai berikut:

1. Kemampuan menulis karangan deskripsi mengalami peningkatan dengan menggunakan metode field trip. Pada penelitian ini yang paling berpengaruh terhadap hasil belajar siswa dari faktor internal siswa berupa perhatian dan motivasi siswa serta faktor eksternal berupa guru, suasana belajar dan sumber belajar. Hal tersebut menyebabkan nilai akhir kelas eksperimen tidak terlalu berbeda jauh dengan kelas kontrol.

2. Penerapan metode field trip dapat meningkatkan aktivitas siswa karena pada metode field trip siswa dituntut untuk aktif dalam pembelajaran dan memberikan pengalaman secara langsung yang merupakan salah satu keunggulan dari metode field trip.

\section{Daftar Pustaka}

Akhadiah, Sabarti dkk. (2001). Pembinaan Kemampuan Menulis Bahasa Indonesia. Jakarta: Erlangga.

Dalman. (2015). Keterampilan Menulis. Jakarta: PT Raja Grapindo Persada.

Finoza, L.(2008). Komposisi Bahasa Indonesia. Jakarta: Insan Mulia.

Hamdayama, Jumanta. (2014). Model dan Metode Pembelajaran Kreatif dan Berkarakter. Bogor: Ghalia Indonesia.

Maryuni. (2007). Ayo Berlatih Mengarang. Surakarta: CV. Mediatama.

Nursisto. (1999). Kiat Menggali Kreativitas. Yogyakarta: Mitra Gama Media.

Roestiyah, NK. (2001). Strategi Belajar Mengajar. Jakarta: Rineka Cipta.

Semi, M.A. (2007). Dasar-dasar Keterampilan Menulis. Bandung: Angkasa. 
Subana dan Sudrajat. (2001). Dasar-dasar Penelitian Ilmah. Bandung: CV. Pustaka Setia. Sugihartono, dkk (2007). Psikologi Pendidikan. Yogyakarta : UNY Press.

Tarigan, H. G. (2008). Menulis sebagai Keterampilan Berbahasa. Bandung: Angkasa. Tim Penyusun KBBI, (2005). Kamus Besar Bahasa Indonesia. Jakarta: Balai Pustaka. 